\title{
Comparative Study on Physicochemical and Biological Parameters of Water among Fish Culture and Reconstructed Pond at Jahangirnagar University Campus, Bangladesh
}

\author{
R. S. Lucy, M. E. Huda and S. M. D. Islam* \\ Department of Environmental Sciences, \\ Jahangirnagar University, Dhaka-1342, Bangladesh \\ *Corresponding author: smdidarulislamju@gmail.com
}

\begin{abstract}
The study was conducted to investigate the physicochemical and biological parameters of fish culture and reconstructed pond at Jahangirnagar university campus. The physicochemical parameters of water in culture and reconstructed pond were analyzed during February to September, 2014 and the mean value of temperature were $30.21 \pm 0.89^{\circ} \mathrm{C}$ and $29.96 \pm 0.91{ }^{\circ} \mathrm{C}$, $\mathrm{pH}$ value were $7.20 \pm 0.29$ and $6.97 \pm 0.39$, Dissolve Oxygen (DO) value were $6.44 \pm 0.40 \mathrm{mg}^{-1}$ and $6.22 \pm 0.30 \mathrm{mg}^{-1}$, Biochemical Oxygen Demand $\left(\mathrm{BOD}_{5}\right)$ value were $1.02 \pm 0.32 \mathrm{mg}^{-1}$ and $0.78 \pm 0.18 \mathrm{mg}^{-1}$, Total Dissolve Solid (TDS) were $0.69 \pm 0.04 \mathrm{mg}^{-1}$ and $0.64 \pm 0.04 \mathrm{mg}^{-1}$, Electric Conductivity (EC) value were $215.38 \pm 21.27 \mu \mathrm{Scm}^{-1}$ and $128.58 \pm 1.10 \mu \mathrm{Scm}^{-1}$. From the study of biological parameter, it was found that Chlorophyceae and Euglenophyceae were dominant in studied ponds and the abundance of phytoplankton are in the order of Chlorophyceae $>$ Euglenophyceae > Bacillariophyceae > Cyanophyceae. The highest productivity was found in culture pond which indicates the suitability of using for aquaculture.
\end{abstract}

Key words: Jahangirnagar University, Phytoplankton, Pond ecology, Water quality

\section{Introduction}

Water is one of the most important and abundant compounds of the ecosystem. All living organisms on the earth need water for their survival and growth (Kumar et al., 2010). The main sources of surface water in Bangladesh are rivers, lakes, canals and ponds (Ahmed and Rahman, 2005). The country's surface water resources are very much essential for human and animal living, aquatic flora and fauna, navigation, fisheries and agriculture etc. (Haque, 2008). The role of water in nature is unique not only from the point of human consideration; even numerous organisms make aquatic medium their habitat. The quality of aquatic life depends on the water quality. In order to utilize fresh water bodies successfully for fish production, it is very important to study the physicochemical factors which influence the biological productivity of the water body. Physical parameters of water quality such as turbidity, conductivity and water mass etc. influence the chemical nature of the water (Gupte and Shaikh, 2013) which regulated by various factors i.e., climatic, geochemical, geomorphological condition and pollutants. But, it is difficult to understand the biological phenomenon fully, because the chemistry of water influences the metabolism of the ecosystem and explain the general hydro-biological relationship (Simpi et al., 2011).

A pond is referred to as a man-made or natural water body which is between $1 \mathrm{~m}^{2}$ and 2 ha $(\sim 5$ acres or $20,000 \mathrm{~m}^{2}$ ) in area, which holds water for four months of the year or more (Biggs et al., 2005). Since, ponds are favorable habitats for a variety of flora-fauna and anthropogenic society, so its regular monitoring is necessary for control. Recently, a lot of work, has been done on changing ecological behavior of ponds (Mahananda et al., 2005; Kanungo et al., 2006; Gupta et al., 2008; Banerjee and Mandal, 2009; Patell and Patel, 2013). Fresh water ecosystem is exploited every possible way and one of it is fish production, which is directly dependent on the productivity of the aquatic ecosystem (Wetzel, 1983; Thakur and Chaudhuri, 2008). To maintain the sound environment and healthy ecosystem of an aquatic body, proper management and monitoring and implementation of existing laws and regulations is necessary (Islam et al., 2015). In limnological studies, to determine of water quality and to identify of algae that composed of primer productivity and to obtain this continuity are well important (Ersanlı and Gönülol, 2003). Primary productivity is the rate, at which the sun's radiant energy is stored by photosynthetic and chemosynthetic activities of producers in the form of organic substances (Odum, 1971). It plays important roles in the penetration, absorption and distribution of light and heat and density stratification in lakes (Cole, 1983). Phytoplanktons are main primary producer in surface waters, so they circumstance are structure and density of consumers and also the physicochemical characteristics of water. Moreover, phytoplankton organisms are sensitive indicators, as the structure and metabolism changes quickly in response to environmental changes (Reynolds, 1996, Thakur and Chaudhuri, 2008). Phytoplankton constitute a major part of aquatic vegetation, they being primary producers which support the growth of aquatic fauna, produce oxygen by photosynthetic process, some of them, because pollution by changing the quality of water in which they grow (Ajayan and Parameswara, 2014). The abundance and taxonomic diversity of plankton depend upon the supply of nutrient in natural waters, where abundance increases with increasing nutrient concentrations. The temperature, $\mathrm{pH}$, dissolved oxygen, alkalinity etc are also important factors for phytoplankton production (Bais and Agarwal, 1990). The relationship between the physical and chemical environment and phytoplankton species composition 
has been the subject of much discussion (Margalef, 1978).

In Bangladesh there are millions of ponds and lakes where extensive fish culture is mainly practiced depending on natural food (phytoplankton) which is produced through fertilization. In some fish farms nutrient concentrations are also increased from different sources such as artificial feeds and fertilizers (both organic and inorganic) etc., which lead to nutrient enrichment in fish ponds. These nutrients eutrify the water body and enable it to support a large variety of phytoplankton assemblage. Actual mechanism of phytoplankton assemblage with the seasonal changes in aquatic environment is very much necessary for the maintenance of water quality and sustainable aquaculture in Bangladesh. Many authors (Islam and Shaha 1975; Wahab and Ahmed, 1992; Saha et al., 1999; Rahman and Hussain, 2008; Khondoker et al., 2012) studied on general limnology of freshwater pond in Bangladesh but seasonal changes in phytoplankton community structure in aquaculture ponds are scarce. Moreover, the knowledge on the limnology and productivity of freshwater reservoir is still need in urban and suburban areas for the planning of aqua cultural practices (Sivakumar and Karuppasamy, 2008). So, the present study was undertaken to investigate the comparison between fish culture and reconstructed pond to understand the effects of fish culture on the productivity of an aquatic ecosystem as well as the seasonal dynamics of different phytoplankton groups in relation to changes in the aquatic environment.

\section{Materials and Methods}

\section{Study area}

The study area was undertaken in the water bodies of Jahangirnagar University Campus.

\section{Sample collection and analysis}

The sampling was carried out at one month interval for maintaining routine monitoring from three locations of each pond, during February-September, 2014. During sampling, $250 \mathrm{ml}$ plastic sample bottles were rinsed with pond water to be sampled three times. Water samples were collected from the depth of about 15-30 $\mathrm{cm}$ from surface and tries to avoided bubble formation and addition of suspended particles as possible. All the samplings were properly labeled and carried out using disposable hand gloves with proper care and stored in ice box. pH, Dissolved Oxygen (DO), Total Dissolved Solids (TDS) of water were measured on spot by using calibrated digital multi-meter $(\mathrm{HACH}, 51910)$ and temperature using mercury centigrade thermometer. Electric conductance (EC) was measured at $25{ }^{\circ} \mathrm{C}$ in $\mu \mathrm{S} / \mathrm{cm}$, using an electric conductivity meter (HANNA, $\mathrm{HI}$ 8033). Biochemical Oxygen Demand $\left(\mathrm{BOD}_{5}\right)$ was done by 5-days incubation, $20^{\circ} \mathrm{C}$ method (APHA, 2005).

\section{Quantification of plankton}

For biological analyses collection, preservation and qualitative assessment of phytoplankton were done by following Khondker et al. (1988) and Johansen (1940) using an electronic microscope. The average number of phytoplankton was expressed per liter of original water by using the following equation:

$$
\text { Phytoplankton }(\text { No. } / \mathrm{ml})=\frac{\mathrm{C} \times 100}{\mathrm{~A} \times \mathrm{D} \times \mathrm{F}}
$$

Where, $\mathrm{C}=$ Total no of phytoplankton counted; $\mathrm{A}=$ Area of field counted; $\mathrm{D}=$ Depth of the field on $\mathrm{mm}$ and $\mathrm{F}=$ No. of fields counted.

\section{Results and Discussion}

\section{Physicochemical parameters}

The colors of the investigated ponds water were observed visually. The observed color was dark green in culture pond and light green in reconstructed pond water. Light green color represented lower planktons, where the dark greenish blue and brown color represented higher planktons (Islam et al., 2015, Sarker et al., 2015). Das (1997) reported that, a well and phytoplankton enriched water body appears to be dark greenish blue, red and brown is good for fishes. Higher plankton concentrations sometime are responsible for blooming, which results less oxygen in water.

Surface water temperature could be influenced by factors such as geographical position, seasonality, diurnal period, circulation of air, quantity of cloud cover, depth of water and its flow rate (Mobin et al., 2014). Temperature of the investigated ponds water found to be more or less similar at different months (Fig. 1a). Water temperature range of all collected samples were $28.60-31.50^{\circ} \mathrm{C}$ for the month of February to September with an average $30.21 \pm 0.90{ }^{\circ} \mathrm{C}$ in the culture pond (Table 1), where these values were 28.4$31.5^{\circ} \mathrm{C}$, average $29.96 \pm 0.89{ }^{\circ} \mathrm{C}$ in the reconstructed pond (Table 2). The highest values were $31.50^{\circ} \mathrm{C}$ for both ponds in the month of May, while the lowest were $28.6^{\circ} \mathrm{C}$ and $28.4{ }^{\circ} \mathrm{C}$ in February for culture and reconstructed pond respectively. According to EQS (1997) standard temperature for surface water is 20 to $30^{\circ} \mathrm{C}$ for sustaining aquatic life and results shows that, temperature of the both ponds are within the limit except in the month of May.

Generally aquatic organisms are affected by $\mathrm{pH}$, because most of their metabolic activities are dependent on it. It is an important indicator of water quality and sustaining life in aquatic ecosystem (Kumar et al., 2011). The $\mathrm{pH}$ of all collected water samples were 6.857.50 with an average $7.20 \pm 0.29$ in the culture pond (Table 1), while these value for reconstructed pond were 6.18-7.40 with average value $6.97 \pm 0.39$ (Table 2). The trend of $\mathrm{pH}$ of the investigated ponds water found to be almost similar at different months (Fig. 1b).The maximum values of $\mathrm{pH}$ were recorded 7.50 and 7.40 for culture and reconstructed pond respectively, while the lowest values were 6.85 and 6.18. Optimal range of $\mathrm{pH}$ for sustainable aquatic life is $6.5-8$ (ECR, 1997) and 
result showed that, $\mathrm{pH}$ values are within the permissible limit except the month of February in reconstructed pond. Similar analysis has done by Patil et al. (2012) and Islam and Azam (2015). Fluctuations in $\mathrm{pH}$ values within different sampling points attributes the factors

Table 1. Monthly variation of average physicochemical parameters of water in culture pond like removal of $\mathrm{CO}_{2}$ by photosynthesis through bicarbonate degradation, dilution of waste with fresh water, reduction of temperature, and decomposition of organic matter (Rajasegar, 2003).

\begin{tabular}{llllllllll}
\hline Months & Feb & Mar & Apr & May & June & Jul & Aug & Sep & Mean \pm SD \\
\hline Temp. $\left({ }^{\circ} \mathrm{C}\right)$ & 28.60 & 29.90 & 30.60 & 31.50 & 31.00 & 29.60 & 30.50 & 30.00 & $30.21 \pm 0.89$ \\
$\mathrm{P}^{\mathrm{H}}$ & 6.85 & 6.98 & 7.50 & 7.25 & 7.50 & 6.85 & 7.13 & 7.50 & $7.20 \pm 0.29$ \\
$\mathrm{DO}\left(\mathrm{mg}^{-1}\right)$ & 6.38 & 5.58 & 6.75 & 6.32 & 6.85 & 6.32 & 6.66 & 6.67 & $6.44 \pm 0.40$ \\
BOD $_{5}\left(\mathrm{mg}^{-1}\right)$ & 0.65 & 0.80 & 0.72 & 0.87 & 1.01 & 1.24 & 1.25 & 1.60 & $1.02 \pm 0.32$ \\
TDS $\left(\mathrm{mg}^{-1}\right)$ & 0.63 & 0.69 & 0.78 & 0.69 & 0.66 & 0.72 & 0.67 & 0.68 & $0.69 \pm 0.04$ \\
EC $(\mu \mathrm{s})$ & 220 & 225 & 230 & 210 & 165 & 225 & 220 & 228 & $215.38 \pm 21.27$ \\
\hline
\end{tabular}

Table 2. Monthly variations of average physicochemical parameters of water in reconstructed pond

\begin{tabular}{llllllllll}
\hline Months & Feb. & Mar. & Apr. & May & June & Jul. & Aug. & Sep. & Mean \pm SD \\
\hline Temp. $\left({ }^{\circ} \mathrm{C}\right)$ & 28.4 & 29.5 & 30.20 & 31.50 & 30.40 & 29.40 & 30.40 & 29.90 & $29.96 \pm 0.91$ \\
$\mathrm{P}^{\mathrm{H}}$ & 6.18 & 6.76 & 7.30 & 7.13 & 7.18 & 6.83 & 6.98 & 7.40 & $6.97 \pm 0.39$ \\
DO $_{\left(\mathrm{mg}^{-1}\right)}^{-1}$ & 6.28 & 5.51 & 6.32 & 6.30 & 6.32 & 6.28 & 6.50 & 6.28 & $6.22 \pm 0.30$ \\
BOD $\left._{5(\mathrm{mg}}\right)$ & 0.41 & 0.75 & 0.65 & 0.85 & 0.88 & 0.89 & 0.90 & 0.93 & $0.78 \pm 0.18$ \\
TDS $_{\left(\mathrm{mg}^{-1}\right)}$ & 0.61 & 0.66 & 0.71 & 0.61 & 0.60 & 0.62 & 0.66 & 0.67 & $0.64 \pm 0.04$ \\
EC $(\mu \mathrm{s})$ & 130 & 127.6 & 129 & 128 & 128 & 130 & 127 & 129 & $128.58 \pm 1.10$ \\
\hline
\end{tabular}

Dissolved oxygen (DO) is one of the most vital parameters in water quality assessment and reflects the physical and biological processes prevailing in the water (Trivedi and Goel, 1984). Adequate DO is necessary for good water quality, survival of aquatic organism and decomposition of waste by microorganism (Islam et al., 2010). Where the rates of respiration and organic decomposition are high, the DO values usually remain lower, than where the rate of photosynthesis is high (Mishra et al., 2009). The DO of all collected water samples were $5.58-6.85 \mathrm{mg}^{-1}$ with an average value of $6.44 \pm 0.40 \mathrm{mg}^{-1}$ in culture pond (Table 1). On the other hand, these values were $5.51-6.50 \mathrm{mg}^{-1}$ with average $6.22 \pm 0.30 \mathrm{mg}^{-1}$ in reconstructed pond for the same month gradually (Table 2). The trend of DO level in investigated ponds found to be almost similar, but some fluctuation observed in case of cultured pond (Fig. 1c). Highest and lowest values were 6.85 and $5.58 \mathrm{mg}^{-1}$ for culture pond during June and March respectively. Where as these values were $6.50 \mathrm{mg}^{-1}$ and $5.51 \mathrm{mg}^{-1}$ for reconstructed pond during August and March respectively. The standard range of DO for fish culture is $5.0 \mathrm{mg}^{-1}$ (Meade, 1998) and more than 5.0 $\mathrm{mg}^{-1}$ (Chowdhury et al., 2007). According to De (2005) the optimum range of DO in natural water is 4.0-6.0 $\mathrm{mg}^{-1}$. Based on the study, the measured values of DO level of all water samples were in good condition. Similar works have done by Rahman and Hussain (2008).

Biochemical oxygen demand $\left(\mathrm{BOD}_{5}\right)$ is a measure of the oxygen in the water that is required by the aerobic organisms (Abida, 2008). High BOD levels indicates lower in DO, because the oxygen that is available in the water is being consumed by the bacteria leading to the inability of fish and other aquatic organisms to survive (Pathak and Limaye, 2011). The BOD $_{5}$ of all collected water sample were within range of $0.65-1.60 \mathrm{mg}^{-1}$ with an average value $1.02 \pm 0.32 \mathrm{mg}^{-1}$ in culture pond (Table 1 ), where the values were $0.41-0.93 \mathrm{mg}^{-1}$ with average $0.78 \pm 0.18 \mathrm{mg}^{-1}$ in reconstructed pond (Table 2). The trend of $\mathrm{BOD}_{5}$ is increasing from February to September; indicate $\mathrm{BOD}_{5}$ is increased in summer (Fig. $2 \mathrm{~d}$ ). The permissible limit for $\mathrm{BOD}_{5}$ for drinking water is $0.2 \mathrm{mg}^{-1}$, for recreation $3 \mathrm{mg}^{-1}$, for fish culture $6 \mathrm{mg} / 1$ and $10 \mathrm{mg}^{-1}$ for irrigation $10 \mathrm{mg}^{-1}$ (ECR, 1997). The $\mathrm{BOD}_{5}$ values obtained in the present study indicated the suitability of pond water for aquatic life.

In water, Total Dissolved Solids (TDS) are composed mainly of carbonates, bicarbonates, chlorides, phosphates and nitrates of calcium, magnesium, sodium, potassium and manganese, organic matter, salt and other particles (Mahananda, 2010). The range of TDS values were $0.63-0.78 \mathrm{mg}^{-1}$ with an average $0.69 \pm 0.04 \mathrm{mg}^{-1}$ for culture pond during study period (Table 1); whereas these values for reconstructed pond were $0.60-0.71 \mathrm{mg}^{-1}$ with average $0.64 \pm 0.04 \mathrm{mg}^{-1}$ consecutively (Table 2). The values of TDS fluctuate with similar pattern in the study period, but slightly higher in culture pond (Fig. 2e). The highest value of TDS in culture pond was $0.78 \mathrm{mg}^{-1}$ in the month of April and lowest $0.63 \mathrm{mg}^{-1}$ during February, while in case of reconstructed pond highest values showed similar to culture pond, but lowest value found in the month of June. Similar works have done by Tavares et al. (2010) and Meghla et al. (2013). 

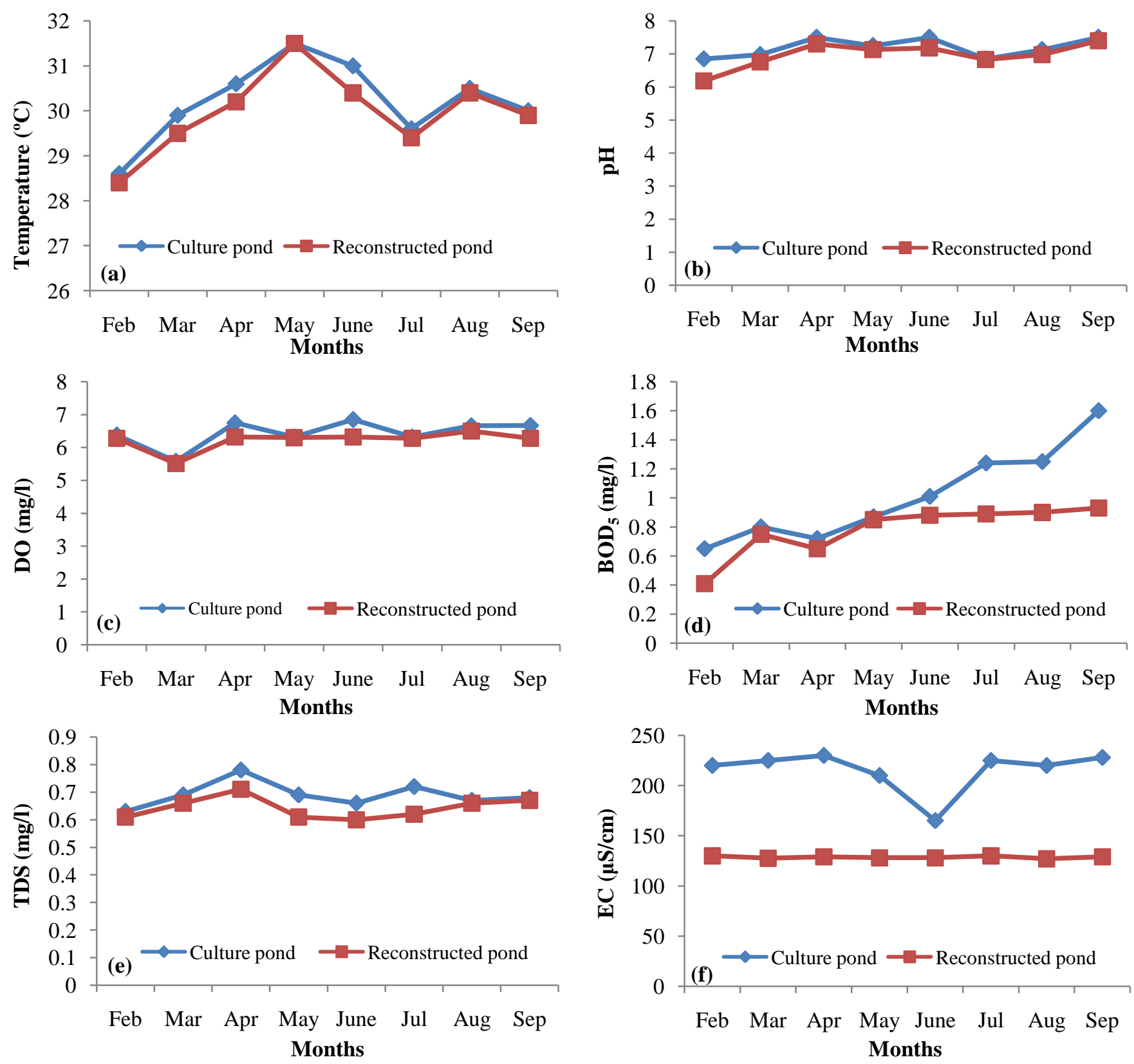

Feb Mar Apr May June Jul Aug Sep Months

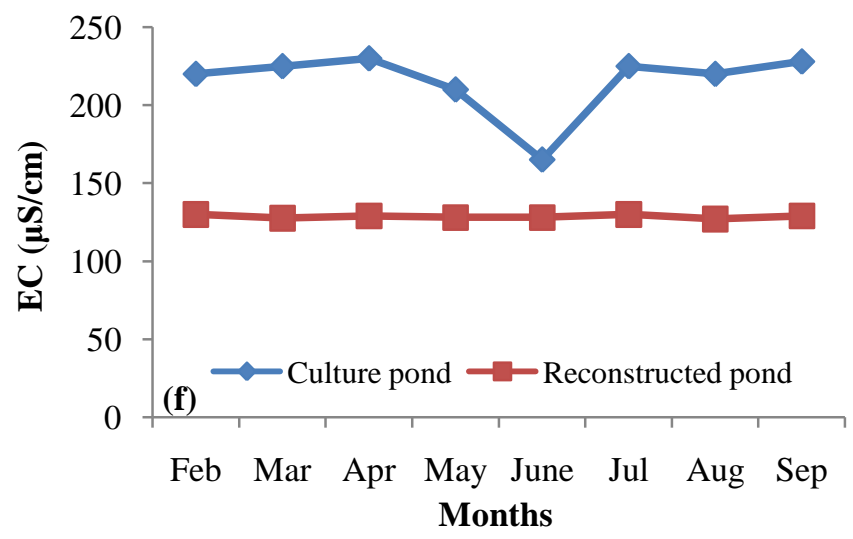

Fig. 1. Comparison of water physicochemical parameters (a) Temperature, (b) pH, (c) DO, (d) BOD 5 , (e) TDS and (f) EC among culture pond and reconstructed pond at $\mathrm{JU}$

Electric conductivity (EC) itself is not a human or aquatic health concern, but it can serve as an indicator of other water quality problems. High values of EC show that a large amount of ionic substances are present in water (Kabir et al., 2002). The conductivity of culture pond is much higher than reconstructed pond indicates; culture pond contains large amount of ionic substances (Fig. 1f). The electric conductivity range were $165-230 \mu \mathrm{S} / \mathrm{cm}$, average $215 \pm 21.12 \mu \mathrm{S} / \mathrm{cm}$ for culture pond (Table 1), while these values for the new constructed pond were $127-130 \mu \mathrm{S} / \mathrm{cm}$ with an average $128.58 \pm 1.10 \mu \mathrm{S} / \mathrm{cm}$ respectively (Table 2). The acceptable range of EC for inland surface water is 1200 $\mu \mathrm{S} / \mathrm{cm}$ (ECR, 1997). From the study, the measured EC of the studied ponds was below than acceptable range.

\section{Biological parameters}

The number of plankton on Cyanophyceae, Chlorophyceae, Bacillariophyceae and Euglenophyceae were showed with monthly variation in culture and reconstructed pond in Table 3 and Table 4, respectively. In culture pond, the average value of Cyanophyceae, Chlorophyceae, Bacillariophyceae and Euglenophyceae were $11.13 \pm 2.9 \quad(9.49 \%), \quad 51.25 \pm 4.50 \quad(43.75 \%)$, $14.00 \pm 3.46(11.95 \%)$ and $40.75 \pm 4.59(34.79 \%) \mathrm{org} / \mathrm{ml}$ (Table 3 ). And in reconstructed pond, the average value of Cyanophyceae, Chlorophyceae, Bacillariophyceae and Euglenophyceae were $9 \pm 3.30(8.98 \%), 40.13 \pm 4.52$ $40.1 \%), 12.88 \pm 3.4812 .9 \%)$ and $38.13 \pm 3.8038 .1 \%)$ org/ml (Table 4), respectively. 
Table 3. Monthly variation of phytoplankton in culture pond (Org./ml)

\begin{tabular}{|c|c|c|c|c|c|c|c|c|c|c|c|c|}
\hline Org. Class & Species Name & $\begin{array}{l}\mathrm{Fe} \\
\mathrm{b}\end{array}$ & $\begin{array}{l}\mathrm{Ma} \\
\mathrm{r}\end{array}$ & $\begin{array}{l}\text { Ap } \\
\mathrm{r}\end{array}$ & $\begin{array}{l}\text { Ma } \\
\mathrm{y}\end{array}$ & $\begin{array}{l}\text { Jun } \\
\mathrm{e}\end{array}$ & $\begin{array}{l}\mathrm{J} \\
\mathrm{ul}\end{array}$ & $\begin{array}{l}\mathrm{Au} \\
\mathrm{g}\end{array}$ & $\begin{array}{l}\mathrm{Se} \\
\mathrm{p}\end{array}$ & $\begin{array}{l}\text { Tota } \\
1\end{array}$ & $\begin{array}{l}\text { Mean } \pm S \\
\text { D }\end{array}$ & $\begin{array}{l}\text { Percentag } \\
\text { e }\end{array}$ \\
\hline \multirow{3}{*}{ Cyanophyceae } & Nostoc sp. & 3 & 3 & 3 & 3 & 3 & 4 & 3 & 4 & \multirow{3}{*}{89} & \multirow{3}{*}{$\begin{array}{l}11.13 \pm 2 . \\
9\end{array}$} & \multirow{3}{*}{$9.49 \%$} \\
\hline & Oscillatoria sp. & 4 & 4 & 4 & 4 & 6 & 5 & 7 & 8 & & & \\
\hline & $\begin{array}{l}\text { Merismopedia } \\
\text { sp. }\end{array}$ & 1 & 1 & 2 & 3 & 3 & 3 & 4 & 4 & & & \\
\hline \multirow{5}{*}{ Chlorophyceae } & Chlorella sp. & 30 & 33 & 34 & 33 & 25 & 3 & 36 & 36 & \multirow{5}{*}{410} & \multirow{5}{*}{$\begin{array}{l}51.25 \pm 4 \\
5\end{array}$} & \multirow{5}{*}{$43.75 \%$} \\
\hline & & & & & & & 3 & & & & & \\
\hline & Volvox sp. & 5 & 5 & 10 & 12 & 15 & $\begin{array}{l}1 \\
7\end{array}$ & 17 & 18 & & & \\
\hline & Spirogyra sp. & 6 & 5 & 3 & 3 & 7 & 3 & 2 & 2 & & & \\
\hline & Ulothrix sp. & 4 & 5 & 1 & 2 & 5 & 1 & 1 & 2 & & & \\
\hline \multirow{4}{*}{$\begin{array}{l}\text { Bacillariophyc } \\
\text { eae }\end{array}$} & Naviculla sp. & 4 & 5 & 6 & 6 & 6 & 6 & 7 & 7 & \multirow{4}{*}{112} & \multirow{4}{*}{$14 \pm 3.46$} & \multirow{4}{*}{$11.95 \%$} \\
\hline & Pinnularia sp. & 2 & 2 & 3 & 4 & 4 & 5 & 5 & 5 & & & \\
\hline & Synedra sp. & 2 & 2 & 1 & 3 & 2 & 3 & 2 & 3 & & & \\
\hline & Melosira sp & 1 & 1 & 2 & 1 & 3 & 2 & 3 & 4 & & & \\
\hline \multirow[t]{2}{*}{$\begin{array}{l}\text { Euglenophycea } \\
\mathrm{e}\end{array}$} & Euglena sp. & 33 & 31 & 33 & 36 & 37 & $\begin{array}{l}3 \\
8\end{array}$ & 40 & 43 & \multirow[t]{2}{*}{326} & \multirow[t]{2}{*}{$\begin{array}{l}40.75 \pm 4 . \\
59\end{array}$} & \multirow[t]{2}{*}{$34.79 \%$} \\
\hline & Phacus sp. & 2 & 5 & 4 & 4 & 5 & 5 & 5 & 5 & & & \\
\hline
\end{tabular}

Table 4. Monthly variation of phytoplankton in reconstructed pond (Org./ml)

\begin{tabular}{|c|c|c|c|c|c|c|c|c|c|c|c|c|}
\hline Org. Class & Species Name & $\begin{array}{l}\mathrm{Fe} \\
\mathrm{b}\end{array}$ & Mar & $\begin{array}{l}\text { Ap } \\
\mathrm{r}\end{array}$ & $\begin{array}{l}\text { Ma } \\
\mathrm{y}\end{array}$ & $\begin{array}{l}\text { Jun } \\
\mathrm{e}\end{array}$ & $\begin{array}{l}\mathrm{Ju} \\
1\end{array}$ & $\begin{array}{l}\mathrm{Au} \\
\mathrm{g}\end{array}$ & $\begin{array}{l}\mathrm{Se} \\
\mathrm{p}\end{array}$ & $\begin{array}{l}\text { Tota } \\
1\end{array}$ & Mean \pm SD & $\begin{array}{l}\text { Percentag } \\
\mathrm{e}\end{array}$ \\
\hline \multirow{3}{*}{ Cyanophyceae } & Nostoc sp. & 1 & 1 & 2 & 2 & 3 & 4 & 3 & 4 & \multirow{3}{*}{72} & \multirow{3}{*}{$9 \pm 3.30$} & \multirow{3}{*}{$8.98 \%$} \\
\hline & Oscillatoria sp. & 3 & 3 & 4 & 3 & 4 & 5 & 7 & 8 & & & \\
\hline & $\begin{array}{l}\text { Merismopedia } \\
\text { sp. }\end{array}$ & 1 & 2 & 1 & 3 & 2 & 1 & 2 & 3 & & & \\
\hline \multirow{5}{*}{ Chlorophyceae } & Chlorella sp. & 23 & 25 & 24 & 23 & 25 & 2 & 30 & 35 & \multirow{5}{*}{321} & \multirow{5}{*}{$\begin{array}{l}40.13 \pm 4.5 \\
2\end{array}$} & \multirow{5}{*}{$40.1 \%$} \\
\hline & & & & & & & 8 & & & & & \\
\hline & Volvox sp. & 5 & 5 & 8 & 9 & 8 & $\begin{array}{l}1 \\
0\end{array}$ & 12 & 6 & & & \\
\hline & Spirogyra sp. & 3 & 3 & 3 & 3 & 3 & 3 & 8 & 4 & & & \\
\hline & Ulothrix sp. & 4 & 3 & 3 & 3 & 3 & 1 & 5 & 3 & & & \\
\hline \multirow{4}{*}{$\begin{array}{l}\text { Bacillariophyce } \\
\text { ae }\end{array}$} & Naviculla sp. & 4 & 5 & 6 & 6 & 6 & 6 & 7 & 7 & \multirow{4}{*}{103} & \multirow{4}{*}{$\begin{array}{l}12.88 \pm 3.4 \\
8\end{array}$} & \multirow{4}{*}{$12.9 \%$} \\
\hline & Pinnularia sp. & 2 & 2 & 3 & 4 & 4 & 5 & 5 & 5 & & & \\
\hline & Synedra sp. & 1 & 1 & 1 & 1 & 2 & 2 & 2 & 3 & & & \\
\hline & Melosira sp & 1 & 1 & 1 & 1 & 2 & 2 & 2 & 3 & & & \\
\hline \multirow[t]{2}{*}{$\begin{array}{l}\text { Euglenophycea } \\
\text { e }\end{array}$} & Euglena sp. & 31 & 30 & 32 & 33 & 34 & $\begin{array}{l}3 \\
4\end{array}$ & 40 & 39 & \multirow[t]{2}{*}{305} & $\begin{array}{l}38.13 \pm 3.8 \\
0\end{array}$ & \multirow[t]{2}{*}{$38.1 \%$} \\
\hline & Phacus sp. & 2 & 5 & 4 & 4 & 4 & 5 & 3 & 5 & & & \\
\hline
\end{tabular}

Chlorophyceae community contains the highest percentage in both ponds. With a few exceptions, among all the groups of phytoplankton recorded, Chlorophyceae and Euglenophyceae showed dominance in all the collected samples from both ponds. Similar observation was also made earlier by Airsang and Lakshman (2013). From productivity analysis, it was found that highest productivity was found in culture pond comparatively. Generally, phytoplankton or algae are indicator of water quality and indicate the suitability of aquatic lives. The higher concentration of plankton in culture pond indicates the suitability of water for fish culture. It is also, indicate that, the newly reconstructed pond need more caution to prepare food when culture activity performs.

\section{Conclusions}

From the investigation of water quality of the two ponds, it was observed that water of the culture pond was more suitable for phytoplankton growth. From productivity analysis, it was also found that highest productivity was found in culture pond and Chlorophyceae and Euglenophyceae were found to be dominant in study area. The higher concentration of 
plankton in culture pond indicates the suitability of water for fish culture. On the other hand, the newly reconstructed pond needs more treatment to prepare food when culture activity performs.

\section{Acknowledgements}

Authors are grateful to the faculty and stuff of Department of Environmental Sciences, Jahangirnagar University for their kind support and cooperation to conduct this work. The authors are also grateful to the reviewers for their valuable suggestion to improve the work before submission.

\section{References}

Abida, B. and Harikrishna. 2008. Study on the quality of water in some streams of Cauvery River. Journal of Chemistry, 5(2):377-384.

Ahmed, M. F. and Rahman, M. M. 2005. Water supply and sanitation, Rural and low income urban communities. ITN-Bangladesh, Center for water supply and waste management, BUET, Dhaka, Bangladesh.

Airsang, R. V. and Lakshman, H. C. 2013. Diversity of Chlorophceae related to physico-chemical parameters in Shetter lake of Navalgund, Dharwad District in Karnataka-India. Science Research Reporter, 3(2):129-134.

Ajayan, K. V. and Parameswara, N. T. 2014. Phytoplankton primary productivity in Lentic water bodies of Bhadravathi Taluk, Shimoga District, Karnataka, India. International Research Journal of Environment Sciences, 3(4):34-41.

APHA (American Public Health Association), 2005. Standard methods for examination of water and wastewater. 21st ed. Washington DC. Pp: 15-36.

Bais, V. S. and Agarwal, N. C. 1990. Seasonal variations of nitrogen contents in the sediment and water of the Sagar lake. Bulletin of Environmental Science, 8:21-24.

Banejee, D. and Mandal, S. 2009. Water quality aspects of some pounds in Asansol. Ecology, Environment and Conservation, 15(1): 145-152.

Biggs, J.; Williams, P.; Whitfield, M.; Nicolet, P. and Weatherby, A. 2005. Aquatic Conservation. Marine and Freshwater Ecosystem, 15:693-714.

Chowdhury, A. M. S.; Rahman, M. A.; Rahman, M. M.; Mohiuddin, A. S. M. and Zaman, M. B. 2007. Nature and the extent of industrial pollution in river water around Dhaka city. Bangladesh Journal of Environmental Science, 13(1):46-49.

Cole, A. G. 1983. Text book of limnology. 3rd edn., C.V. Mosby Co., London. pp: 401.

Das, B. 1997. Fisheries and fisheries resources management. Bangla Academy, Dhaka, Bangladesh. pp:153-155.

De, A. K. 2005. Environmental Chemistry. 5th ed. New Age International (P) Ltd., Daryagang, New Delhi, India. Pp:187.

ECR (Environmental Conservation Rules), 1997. Government of the People's Republic of
Bangladesh. Ministry of Environment and Forest, Department of Environment, Dhaka, Bangladesh. pp: 212-214.

EQS (Environmental Quality Standard), 1997. Government of the People's Republic of Bangladesh. Ministry of Environment and Forest, Department of Environment, Gazette, registered nr. DA-1, Dhaka, Bangladesh.

Ersanl1, E. and Gönülol, A. 2003. Study on the phytoplankton and seasonal variation of lake simenit (Terme - Samsun, Turkey). Turkish Journal of Fisheries and Aquatic Sciences, 3:2939.

Gupte, A. and Shaikh, N. 2013. Seasonal variations in physicochemical parameters and primary productivity of Shelar lake Bhiwandi, Thane, Maharashtra. Universal Journal of Environmental Research and Technology, 3(4):523-530.

Gupta, S. K., Tiwari, N. P. and Alam, M. N. 2008. Studies on physcochemical status of two ponds at Patan in relation to growth of fishes. Nat. Env \& Poll. Tech., 7(4) :729-732.

Haque, M. I. 2008. Water resources management in Bangladesh. Anushila, Chuadanga and Dhaka, pp. 24-84.

Islam, A. K. M. N. and Shaha, J. K. 1975. Limnologycal studies of the Ramna Lake in Dhaka. Dhaka University Studies (BD), 23:39-46.

Islam, M. S.; Rehnuma, M.; Tithi, S. S.; Kabir, M. H. and Sarkar, L. 2015. Investigation of water quality parameters from Ramna, Crescent and Hatirjheel Lakes in Dhaka City. Journal Environmental Science and Natural Resources, 8(1):1-5.

Islam, S. M. D. and Azam, G. 2015. Seasonal variation of physicochemical and toxic properties in three major rivers; Shitalakhya, Buriganga and Turag around Dhaka city, Bangladesh. Journal of Biodiversity and Environmental Sciences, 7(3):120131.

Johansen, D. 1940. Plant micro technique. McGraw Hill Book Company Inc. New York. Pp: 523.

Kabir, E. S.; Kabir, M.; Islam, S. M.; Mia, C.M.; Begum, N.; Chowdhury, D. A.; Sultana, S.M. and Rahman, S.M. 2002. Assessment of effluent quality of Dhaka export processing zone with special emphasis to the textile and dying industries". Jahangirnagar University Journal of Science, 25: 137-138.

Kangugo, V. K.; Verma, J. N. and Patel, D. K. 2006. Physicochemical characteristics of doodhadahri pond of Rainpur, Chattisgarh. Ecology Environment and Conservation, 12(2):207-209.

Khondker, M.; Islam, A. K. M. N. and Islam, R. 1988. Studies on the primary productivity of Dhanmondi Lake. Dhaka University Studies, Part-E, 3(1):1521.

Kumar, G. N. P.; Srinivas, P.; Chandra, G. K. and Sujatha, P. 2010. Delineation of groundwater potential zones using remote sensing and GIS techniques: A case study of KurmapalliVagu Basin 
in Andhra Pradesh, India. International Journal of Water Resources and Environmental Engineering, 2(3):70-78.

Kumar, V.; Arya, S.; Dhaka, A. and Minakshi, C. 2011. A study on physico-chemical characteristics of Yamuna River around Hamirpur (UP), Bundelkhand region central India. International Multiple Research Journal, 1(5):14-16.

Mahananda, H. B.; Mahananda, M. R. and Mohanty, B. P. 2005. Studies on the physicochemical and biological parameters of a fresh water pond ecosystem as an indicator of water pollution. Ecology Environment and Conservation, 11(3-4): 537-541.

Mahananda, M. R. 2010. Physico-chemical analysis of surface water and ground water of Bargarh District, Orissa, India. International Journal of Research and Review in Applied Sciences, 2(3):284-295.

Margalef, R. 1978. Life forms of phytoplankton as survival alternatives in an unstable environment. Oceanologia Acta, 1:493-509.

Meade, J. W. 1998. Aquaculture Management. CBS Publishers \& Distributors, New Delhi, India. Pp: 9.

Meghla, N. T.; Islam, M. S.; Ali, M. A.; Suravi and Sultana, N. 2013. Assessment of Physicochemical Properties of Water from the Turag River in Dhaka City, Bangladesh. International Journal of Current Microbiology Applied Science, 2(5):110-122.

Mishra, A.; Mukherjee, A.; Tripathi, B. D. 2009. Seasonal and temporal variation in physicochemical and bacteriological characteristics of River Ganga in Varanasi. International Journal of Environmental Research, 3(3):395-402.

Mobin, M. N.; Islam, M. S.; Mia, M. Y. and Bakali, B. 2014. Analysis of physicochemical properties of the Turag River water, Tongi, Gazipur in Bangladesh. Journal of Environmental Science \& Natural Resources, 7(1):27 - 33 .

Odum, E. P. 1971. Fundamentals of Ecology. W.B. Sunders, Toppan Co. Ltd., Tokyo, Japan.

Patel, A. C. and Patel, R. S. 2013. Comparison of the physicochemical parameters of two lakes at Lodra and Soja under biotic stress. International Journal of Innovative Research in Science, Engineering and Technology, 2(5):1860-1864.

Pathak, H. and Limaye, S. N. 2011. Interdependency between physicochemical water pollution indicators: A case study of River Babus, Sagar, M.P., India, AnaleleUniversităŃii din Oradea - SeriaGeografie (June) Article no. 211103-515. Pp: 23-29.

Patil, P. N.; Sawant, D. V. and Deshmukh, R. 2012. Physico-chemical parameters for testing of water -
A review. International Journal of Environmental Science, 3(3):1194-1207.

Rahman, S. and Hussain, M. A. 2008. A study on the abundance of zooplankton of a culture and a nonculture pond of the Rajshahi University campus. University Journal of Zoology, Rajshahi University, 27:35-41.

Rajasegar, M. 2003. Physico-chemical characteristics of the Vellar estuary in relation to shrimp farming. Journal of Environmental Biology, 24:95-101.

Reynolds, C. S. 1996. The plant life of the pelagic. Verh. Int. Ver.Limnol. 26:97-113.

Saha, D. K.; Azad; Shah, A. K. M.; Islam, M.S.; Bhandari, R. K. and Rahman, M. S. 1999. Effects of fertilization on the production of Indian major carps. Bangladesh Journal of Fisheries, 21:33-38.

Saleheen, M. 2012. Jahangirnagar University. In Islam, Sirajul; Jamal, Ahmed, A. Banglapedia: National Encyclopedia of Bangladesh (Second edn.). Asiatic Society of Bangladesh.

Sarker, M. R. S.; Islam, A.; Islam, A.; Hoque, M. M. and Roy, S. 2015. Seasonal variation in quality of Louhajong river water, Tangail. Bangladesh Journal of Scientific Research, 28(1):9-16.

Simpi, B.; Hiremath, S. M.; Murthy, K. N. S.; Chandrashekarappa, K. N.; Anil, N.; Patel and Puttiah, E.T. 2011. Analysis of water quality using physicochemical parameters Hosahalli Tank in Shimoga District, Karnataka, India. Global Journal of Science Frontier, Research, 1(3):31-34.

Sipaúba-Tavares, L. H.; Donadon, A. R. V. and Milan, R. N. 2010. Water quality and plankton populations in an earthen polyculture pond. Brazilian Journal of Biology, 71(4):845-855.

Sivakumar, K. and Karuppasamy, R. 2008. Factors affecting productivity of phytoplankton in a reservoir of Tamilnadu, India. American-Eurasian Journal of Botany, 1 (3):99-103.

Thakur, A. R. and Chaudhuri, S. R. 2008. Phytoplankton diversity as indicator of water quality for fish cultivation. American Journal of Environmental Sciences, 4 (4):406-411.

Trivedi, R. K. and Goel, P. K. 1984. Chemical and biological methods for water pollution studies. Environmental Publications, Karad. Pp: 211-215.

Wahab, M. A. and Ahmed, Z. F. 1992. Effect of planktivorous carp species combination on food organisms and electivity indices in the fish ponds. Progressive Agriculture, 2:21-30.

Wetzel, R. G.1983. Limnology, 2nd edn. Saunders Co., Philadelphia. 